\title{
Kentsel Çevre ve Sağlık Bağlamında Van Depreminden Çıkarılan Dersler
}

\section{Bilge Kalanlar ${ }^{1, *}$}

${ }^{1}$ Hacettepe Üniversitesi, Hemşirelik Fakültesi, 06100, Ankara.

\section{Özet}

23 Ekim ve 9 Kasım depremlerinde Türkive'nin Van Ilinde birçok insan hayatını kaybetmiștir. Deprem çok kuvvetli bir șekilde hissedilmiş olup, bölgede yıkıcı hasar yaratmış ve çok sayıda can kaybına yol açmıştır. Van depremi gerçeği kentlerin afete daha hazırlıklı olması açısından en yakın örnektir. Bu bağlamda çalışmada amaç, Van depreminde gözlenen problemlerin ve çıkarılan derslerin kentsel çevre ve sağllk açısından ele alınmasıdır. Kentsel çevre ve sağlık açısından Van depremi değerlendirilmiş ve çalı̧̧ma değerlendirme makalesi olarak kurgulanmıştır. Çalışma Van depreminde yazarın gözlemleri ve ulusal ve uluslararası literatür bağlamında ele alınmıştır. Kentsel çevre ve sağlık açısından Van depremi sonrasında afetzedelere birinci basamak sağlık hizmetlerinin afetzedelere sunulması ve bunun sürdürülebilirliğinin aksadığı görülmüştür. Afetzedelerin içme suyu, gıda, barınma, ısınma, giysi, tuvalet, yıkanma, çöp - atık uzaklaştırma gibi gereksinimlerinin sağlıklı olarak sağlanmasında sorunlar olduğu tespit edilmiştir. Uygun barınma ve sanitasyon șartlarının sağlanmasında sorunlar yaşandığ ve alt yapı hizmetlerinde sorunlar olduğu görülmüş̧ür. Bu bağlamda afetlerde yaşanan deneyimlerin bilgi olarak aktarllmasl, kentlerin gelecekte yaşanacak depremlere hazırlıklı olmak açısından oldukça önemlidir. Kentsel çevre ve sağllk açısından depremlerde etkin planlama yapılması, ölüm ve yaralanmalar için risk faktörlerinin epidemiyolojik analizi, depremlerde acil ihtiyaç değerlendirmesi için gerekli bilgi, kurtarma faaliyetleri, kayıpların yönetimi, tıbbi malzemeler, hastallk kontrol ve sanitasyon ve diş yardım konularının deprem öncesi, sirası ve sonrasinda olmak üzere afetin tüm evrelerinin önceden planlanmasl gerektiği değerlendirilmektedir. Ayrica kentsel çevre ve sağllk bağlamında afete hazırlıklı olma noktasında kentlerimizde veya belirlenecek ortak noktalarda kısllk çadır, konteyner depoları oluşturulması gerektiği, depolarda afetzedeler için ve sağlık personelleri için gerekli uyku tulumu, stok imkânı bulunan malzemelerin bulundurulması gerektiği en önemli bulgulardır.

\section{$\underline{\text { Anahtar Sözcükler }}$}

Van Depremi, Kentsel Çevre, Sağlık

\section{Lessons Learned from Van Earthquake in the Context of Urban Environment and Health}

\begin{abstract}
Many people have lost their lives on October 23 and November 9 earthquake in Van province of Turkey. Earthquake was felt very vigorous in Van and caused devastating casualties because of its building stock and have led to numerous loss of life. The reality of Van earthquake is the most recent example in terms of being more prepared for disasters. In this context the aim of this study is to address the problems observed in Van earthquake and lessons learned in terms of the urban environment and health. Van earthquake was evaluated in terms of the urban environment and health and study designed as an evaluation article. Earthquake observations of author is evaluated and discussed in the context of national and international literature. Delivery of the primary health care to the victims after the Van earthquake has delayed and had some problems to continue it without interruption. Drinking water, food, shelter, heat, clothing, toiletries, washing, waste - waste disposal has been determined as problems in ensuring in a healthy way to the victims. It has been observed that there are problems to ensure appropriate shelter and had some problems in infrastructure services. In this context, it is very important to share the information of experience lived in terms of being prepared for an earthquake will happen in the future. The urban environment and health in terms of effective planning done in the earthquake, epidemiological analysis of risk factors for death and injury, the necessary information for emergency needs assessment in earthquake rescue operations, management of losses, medical supplies, disease control and pre-earthquake sanitation and foreign aid issues, during and after disasters, including all stages of disaster should be evaluated and planned in advance. In addition, disaster in our city or in common areas on the point of being prepared, determined winterized tents, container depots should be created to store the offered guaranteed health and needed sleeping bags for staff, food supplies which have available stock opportunities, catalytic stoves, cleaning supplies, portable toilets, kitchen are the most important findings are issued in the context of the urban environment and health.
\end{abstract}

$\underline{\text { Keywords }}$

Van Earthquake, Urban Environment, Health 


\section{Giriş}

Van depremi, 23 Ekim 2011 günü meydana gelmiş ve toplam 644 kişi hayatını kaybetmiş, 1.966 kişi yaralanmış, 252 kişi enkazlardan sağ olarak kurtarılmıştır. Deprem, Van ve çevresinde çok kuvvetli bir şekilde hissedilmiş olup, yıkıcı hasar yaratmış ve çok fazla sayıda can kaybına yol açmıştır. Depremin büyüklüğü; Kandilli Rasathanesi tarafından Richter ölçeğine göre 7,2 olarak belirtilmiştir. Deprem sonucu açığa çıkan enerji miktarının oldukça büyük olduğu, 23 Ekim'de ana şokun oluşturduğu enerjinin, meydana gelen artçılar da hesaba katıldığında Hiroşima'ya atılan atom bombasının 37 katına denk olduğu kaydedilmiştir. Ayrıca, depremin birinci haftasında bölgede büyüklüğ̈̈ 4,0-4,9 arasında değişen deprem sayısı 187,5 'ten büyük olan deprem sayısı ise 13 olmuş, ilk ay içinde bölgede her gün ortalama 180 artçı deprem meydana gelmiştir (URL-1 2011). Çalışmada kentsel çevre ve sağlik açısından Van depremi değerlendirilmiş ve Van depreminde gözlemlerden elde edilen sonuçlar derleme olarak yazılmıştır. Çalışma Van depreminde yazarın gözlemleri ve ulusal ve uluslararası literatür bağlamında ele alınmıştır. Kentsel çevre ve sağlık açısından Van depremi sonrasında afetzedelere birinci basamak sağlık hizmetleri sunulması ve bunun kesintisiz olarak sürdürülmesi sürecinin aksadığı görülmüştür. Afetzedelerin içme suyu, barınma, ısınma, gıda, giysi, tuvalet, yıkanma, çöp - atık uzaklaştırma vb gereksinimlerinin sağlıklı olarak sağlanmasında sorunlar olduğu tespit edilmiştir. Uygun barınma ve sanitasyon şartlarının sağlanmasında sorunlar yaşandığı ve alt yapı hizmetlerinde sorunlar olduğu görülmüştür. Bu bağlamda afetlerde yaşanan deneyimlerin bilgi olarak aktarılması, kentlerin gelecekte yaşanacak depremlere hazırlıklı olmak açısından oldukça önemlidir. Kentsel çevre ve sağlık açısından depremlerde etkin planlama yapılması, ölüm ve yaralanmalar için risk faktörlerinin epidemiyolojik analizi, depremlerde acil ihtiyaç değerlendirmesi için gerekli bilgi, kurtarma faaliyetleri, kayıpların yönetimi, tıbbi malzemeler, hastalık kontrol ve sanitasyon ve dış yardım konularının deprem öncesi, sırası ve sonrasında olmak üzere afetin tüm evrelerinin önceden planlanması gerekmektedir. Bu bağlamda çalışmada amaç, Van depreminde gözlenen problemlerin ve çıkarılan derslerin kentsel çevre ve sağlık açısından ele alınmasıdır. Afetler konusunda yaşanmış olaylara yaklaşım, bu olaylardaki deneyimler, bu alanlarda çalışma yapılmasının zorluğundan dolayı bilimsel olarak çok değerlidir. Deprem kuşağındaki Türkiye'de yaşanan depremler tüm dünya için ders olabilecek sonuçlara yol açmaktadır. Afete yanıt ve afet yönetimi konusu, afet öncesi sırası ve sonrasında titizlikle ele alınması gereken konular arasındadır. Afet durumlarındaki deneyimler, gözlemler ve çıkarımların anlam kazanması için literatüre kazandırılması gerekir. Deneyimlerin paylaşımı; olası olaylara karşı hazırlık yapılmasını ve afet yönetiminin her aşamasının en uygun şekilde yürütülebilmesini sağlayacaktır. Bu bağlamda makalede amaç; afet deneyimi ve gözlem paylaşımı ile geleceğe yönelik iyileştirmeler yapılmasına yardımcı olmak ve afet bilimine katkı sağlamaktır.

\section{Van Depremi}

Her gün dünyanın herhangi bir yerinde afetler olmakta ve bu afetler bireyleri, aileleri ve toplumları olumsuz yönde etkilemekte, insanların yaşam kalitesini tehdit etmektedir (Minami ve Young 2009). Doğal afet türleri içinde olan deprem, en fazla mal ve can kaybına sebep olan afet türlerinden birisidir ve dünyada gelişmiş ve gelişmekte olan tüm ülkeler için önemli bir sorun oluşturmaktadır. Başbakanlık Afet ve Acil Durum Yönetimi Başkanlığının (AFAD) Van Depremleri Faaliyet Raporu'nda (URL-1 2011) belirtildiğine göre; 23 Ekim ve 9 Kasım depremlerinde Van İlinde toplam 644 kişi hayatını kaybetmiştir. Yine 13 Aralık 2011 itibariyle AFAD Van Depremleri Faaliyet Raporu'na göre; 23 Ekim 2011 günü meydana gelen Van-Erciş merkezli deprem ve 9 Kasım 2011 günü yaşanan Van-Edremit merkezli deprem (Şekil 1); yıkıcı hasar yaratmış ve çok sayıda can kaybına yol açmışıtır. Bölgeye toplam 2.976 sağlık personeli gönderilmiştir. Hizmet verebilen 4 hastanenin yanında, 6 sahra hastanesi kurulmuştur. 12 mobil sağlık aracı, 20 ambulans, 18 UMKE aracı ile birlikte yaklaşık 12 bin kişiye gezici sağlık hizmeti verilmiş̧ir.

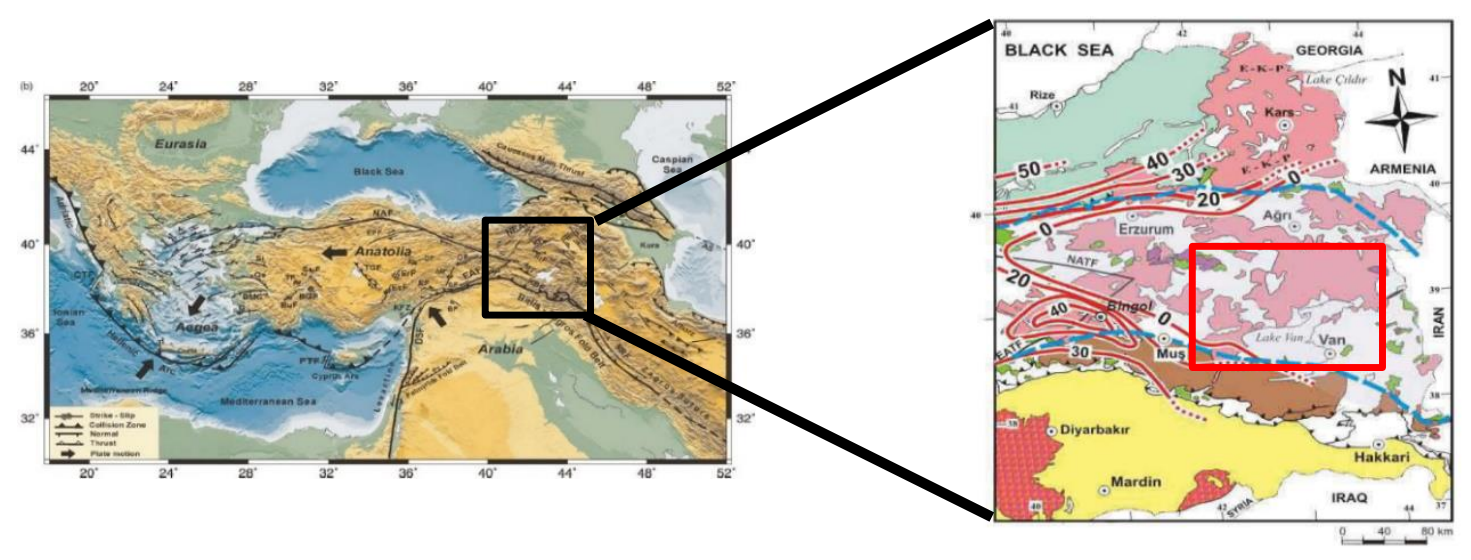

Şekil 1: Van depremi (URL-1 2011) 
Van ve çevresinin deprem geçmişine ilişkin Şekil 2 ve Van ilinde son 5 yılda meydana gelen en büyük depremler büyüklüklerine göre aşağıda Tablo 1'de verilmiştir. Elde edilen verilere göre Van ve çevresinde 2011 yılında Van İlinde, 1976 yılında Çaldıran'da, 1930 yılında İran Salmas'ta ve son olarak ta, 1903 yılında Muş-Malazgirt'te önemli sayılabilecek büyüklükte depremler meydana gelmiştir. Van ilinde son 5 yılda meydana gelen en büyük depremler büyüklüklerine göre incelendiğinde ise bölgede depremlerin 4,6 ile 6,6 şiddetleri arasında değiştiği görülmektedir.

Tablo 1: Van ilinde son 5 yılda meydana gelen en büyük depremler (2011-2016 yılları arası) (URL-2 2016)

\begin{tabular}{|c|c|c|c|c|}
\hline Tarih & Saat & Deprem Bölgesi & Şiddet & Büyüklük \\
\hline 23 Ekim 2011 & $13: 41$ & TABANLI-- (VAN) İlksel & VII-IX & 6.6 \\
\hline 23 Ekim 2011 & $13: 41$ & TABANLI-- (VAN) İlksel & VII-IX & 6.6 \\
\hline 23 Ekim 2011 & $23: 45$ & MOLLAKASIM-- (VAN) İlksel & VI & 5.7 \\
\hline 23 Ekim 2011 & $23: 45$ & MOLLAKASIM-- (VAN) İlksel & VI & 5.7 \\
\hline 09 Kasım 2011 & $21: 23$ & EDREMIT (VAN) İlksel & VI & 5.6 \\
\hline 09 Kasım 2011 & $21: 23$ & EDREMIT (VAN) İlksel & VI & 5.6 \\
\hline 09 Kasım 2011 & 00:05 & VAN GÖLÜ REVIZE01 (2011.11.09 00:05:50) & VI & 5.5 \\
\hline 23 Ekim 2011 & $13: 56$ & GEDIKBULAK-- (VAN) İlksel & VI & 5.5 \\
\hline 23 Ekim 2011 & $14: 32$ & HALKALI-- (VAN) İlksel & VI & 5.5 \\
\hline 25 Ekim 2011 & $17: 55$ & DEGIRMENOZU-- (VAN) İlksel & VI & 5.4 \\
\hline 23 Ekim 2011 & $13: 48$ & ILIKAYNAK-- (VAN) İlksel & VI & 5.4 \\
\hline 30 Ekim 2011 & $01: 24$ & COLPAN-- (VAN) REVIZE01 (2011.10.30 01:24:21) & VI & 5.3 \\
\hline 15 Kasim 2011 & 00:08 & MOLLAKASIM- (VAN) REVIZE01 (2011.11.15 00:08:15) & VI & 5.2 \\
\hline 24 Haziran 2012 & 23:07 & KARAGUNDUZ-(VAN) & VI & 5.0 \\
\hline 30 Kasım 2011 & 02:47 & KURUBAS- (VAN) İlksel & VI & 5.0 \\
\hline 23 Ekim 2011 & $21: 10$ & GOLLU-- (VAN) REVIZE01 (2011.10.23 21:10:45) & VI & 5.0 \\
\hline 20 Ocak 2012 & $11: 57$ & ADIGUZEL-(VAN) & IV-V & 4.9 \\
\hline 05 Aralık 2011 & 00:15 & KAVURMA- (VAN) İlksel & IV-V & 4.9 \\
\hline 18 Kasım 2011 & $19: 39$ & BODURAGAC-OZALP (VAN) REVIZE01 & IV-V & 4.9 \\
\hline 06 Kasım 2011 & 04:43 & COLPAN- (VAN) İlksel & IV-V & 4.9 \\
\hline 23 Ekim 2011 & $21: 53$ & SAHGELDI-- (VAN) İlksel & IV-V & 4.9 \\
\hline 23 Ekim 2011 & $21: 53$ & SAHGELDI-- (VAN) İlksel & IV-V & 4.9 \\
\hline 23 Ekim 2011 & $22: 06$ & YESILSU-- (VAN) İlksel & IV-V & 4.9 \\
\hline 02 Kasım 2011 & $06: 34$ & CAKIRBEY- (VAN) İlksel & IV-V & 4.8 \\
\hline 24 Ekim 2011 & $18: 28$ & ALAKOY-- (VAN) İlksel & IV-V & 4.8 \\
\hline 24 Şubat 2012 & 15:07 & AKCIFT-(VAN) & IV-V & 4.7 \\
\hline 24 Şubat 2012 & 15:07 & AKCIFT-(VAN) & IV-V & 4.7 \\
\hline 06 Aralık 2011 & $04: 55$ & ERISEN-MURADIYE (VAN) İlksel & IV-V & 4.7 \\
\hline 22 Kasım 2011 & $05: 30$ & YESILKOY-(VAN) İlksel & IV-V & 4.7 \\
\hline 17 Kasım 2011 & $14: 38$ & COLPAN- (VAN) İlksel & IV-V & 4.7 \\
\hline 07 Kasım 2011 & $17: 53$ & KARAGUNDUZ- (VAN) İlksel & IV-V & 4.7 \\
\hline 02 Kasım 2011 & $15: 24$ & AKCIFT- (VAN) İlksel & IV-V & 4.7 \\
\hline 23 Ekim 2011 & $14: 10$ & KURUBAS-- (VAN) REVIZE02 (2011.10.23 14:10:45) & IV-V & 4.7 \\
\hline 24 Haziran 2015 & $01: 35$ & MOLLAKASIM-(VAN) & IV-V & 4.6 \\
\hline 18 Şubat 2014 & $23: 51$ & AKCIFT-(VAN) & IV-V & 4.6 \\
\hline 12 Haziran 2013 & 22:02 & GOVELEK-(VAN) (2013.06.12 22:02:51) & IV-V & 4.6 \\
\hline 04 Nisan 2012 & $12: 41$ & CAKIRBEY-(VAN) & IV-V & 4.6 \\
\hline 22 Kasım 2011 & $05: 30$ & TOPAKTAS- (VAN) İlksel & IV-V & 4.6 \\
\hline 08 Kasım 2011 & $00: 14$ & SAGLAMTAS- (VAN) İlksel & IV-V & 4.6 \\
\hline 25 Ekim 2011 & $02: 55$ & ASAGIGOLALAN-- (VAN) İlksel & IV-V & 4.6 \\
\hline 24 Ekim 2011 & $11: 28$ & BARDAKCI-- (VAN) İlksel & IV-V & 4.6 \\
\hline 24 Ekim 2011 & $11: 49$ & KOZLUCA-- (VAN) İlksel & IV-V & 4.6 \\
\hline 23 Ekim 2011 & $18: 57$ & GUVENCLI-- (VAN) İlksel & IV-V & 4.6 \\
\hline 14 Mart 2011 & $20: 57$ & SARAY (VAN) & IV-V & 4.6 \\
\hline
\end{tabular}




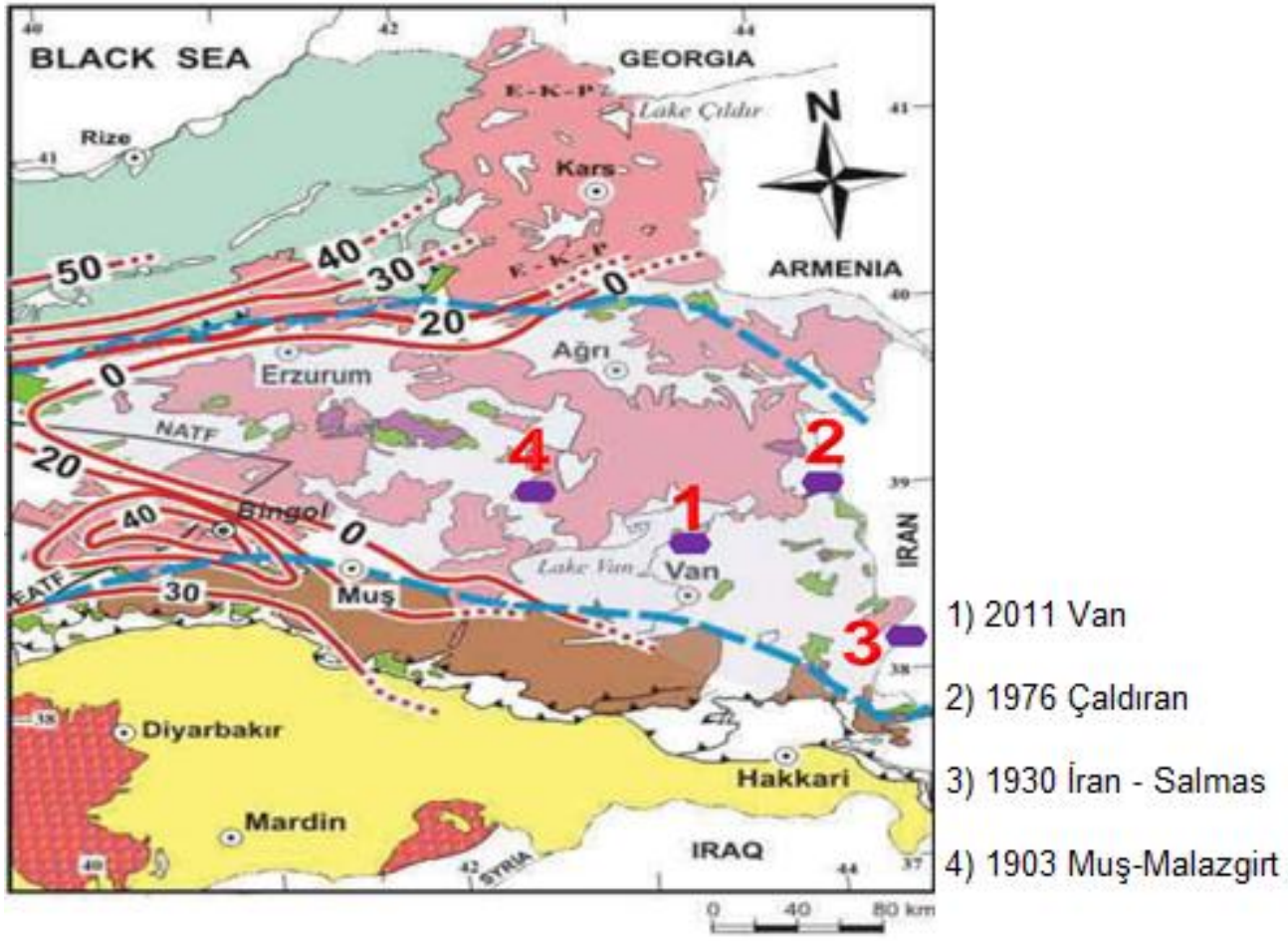

Şekil 2:Van ve Çevresinin Deprem Geçmişi (Pınar vd. 2012)

\section{Halk Sağlığı Açısından Van Depremi}

Olası afetlerde kayıplarımızı en aza indirmek için; yaşadığımız ortamların yaratacağı riskleri öngörmek ve bu risklere karşı tedbir almak hayati açıdan önemlidir. Ancak her ne kadar tedbir alırsak alalım insanoğlu doğa ile olan mücadelesinde genellikle zor duruma düşmekte, büyük kayıplar yaşamaktadır. Oluşan her afette öncelik insanların hayatta kalmasının sağlanmasıdır. Zira tüm tıbbi müdahalelerin temel hedefi insanı hayatta tutmaktır. Bu bağlamda Van depremi halk sağlığı boyutu ile değerlendirilecek olursa, konunun hemşirelik uygulamaları açısından ele alınması gerekecektir. Zira hemşireler sağlık profesyonelleri içerisinde sayıca en fazla çalışana sahip afetlerde görev alacak meslek grupları içerisinde yer almaktadır. Afetler halk sağlığı ve hemşirelik uygulamaları açısından değerlendirildiğinde; afet yönetim sistemleri içerisinde hemşirelerin her yerde ve her koşulda etkin bir rol almalarının faydalı olacağı görülmektedir (Kalanlar 2012). Mesleki rol ve sorumluluklarını dikkate alarak, ülke genelinde hazırlanmış olan ulusal afet yönetim planlamalarının her aşamasında, hemşireler hemşirelik sürecini kullanarak aktif rol alabilmelidir. Hizmet içi eğitim programları, sertifika programları gibi sürekli eğitim planları yolu ile afetlere ilişkin bilgilerin güncellenmesi ve sağlık çalışanlarının planlama içerisindeki görevlerine hâkim olması gerekmektedir (Kalanlar ve Kubilay 2015). Bu eğitimler kapsamında, teorik eğitimler dışında, çeşitli yurtdışı örneklerinde olduğu gibi karmaşık ya da zarar görmüş alanda nasıl acil sağlık hizmetini yürüteceği, bireylere nasıl, nerede bakım vereceğinin uygulamalı olarak eğitimden geçirilmesi gerekmektedir. Bununla birlikte, hemşirelerin afet yönetiminde sürekli aynı görevi yaparak değil, rotasyonlar şeklinde planın farklı evrelerinde yer alması sağlanarak, tükenmişlik, stres, anksiyete düzeyleri en aza indirilmeli ve etkin bir takım çalışması ile motive bir halde çalışmalarını yürütebilmesinin de planlanması gerekmektedir (Kalanlar 2013; Kalanlar 2014).

Yaşanan tüm sorunların ve çözüm önerilerinin 1şı̆̆ında, ülke genelinde ilgili tüm kurum ve kuruluşlar bazında modern bir afet yönetim planı hazırlanmalı ve bu plan içerisinde güçlü bir kaynak olan hemşireye, hemşirelik ile ilgili tüm kurum, kuruluş ve derneklere etkin görev, rol ve sorumluluklar verilebilmelidir.

Tüm afet durumlarında özellikle depremlerde etkin planlama yapılması için ölüm ve yaralanmalar için risk faktörlerinin epidemiyolojik analizi, deprem yaralanma epidemiyolojisi, depremlerde acil ihtiyaç değerlendirmesi için gerekli bilgi, kurtarma faaliyetleri, kayıpların yönetimi, tıbbi malzemeler, hastalık kontrol ve sanitasyon ve dış yardım, karar verme süreçleri, eğitim ve uygulamalar konularının deprem öncesi, sırası ve sonrasında olmak üzere sürekli olarak araştırılması ve geliştirilmesi gerekliliği literatürde kapsamlı olarak vurgulanmaktadır (Slepski 2007; Hilton vd. 2005; Veenema 2003; Priest 2009; Kennedy vd. 2009). Bu bağlamda aşağıdaki fotoğraflarda Van depremi özelinde ders alınması gereken noktalar vurgulanmış ve resmedilmiştir. 

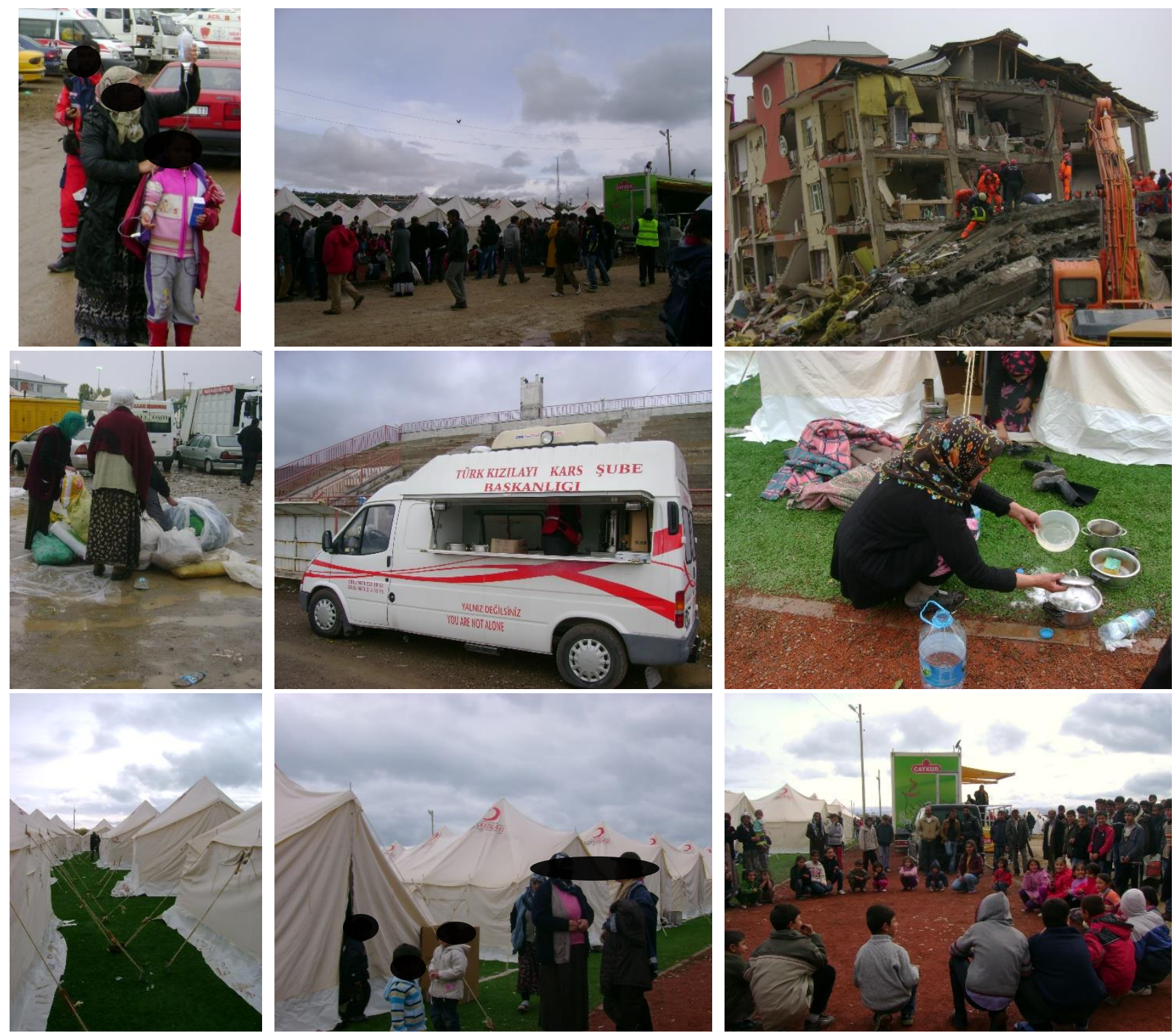

Şekil 3: Van depreminden görüntüler (Fotoğraflar yazarın veri tabanından alınmıştır)

\subsection{Kentsel Çevre Açısından Van Depremi}

Van depremi gerçeği kentlerin afete daha hazırlıklı olması açısından en yakın örnektir. Bu bağlamda bu bölümde, Van depreminde gözlenen problemlerin ve çıkarılan derslerin kentsel çevre açısından ele alınmıştır. Kentsel çevre ve sağlık açısından Van depreminde; depreme dayanıklılık yönünden sağlık hizmeti verilebilecek güvenli bina kalmamış olması en büyük sorunlardan birisi olmuştur. Sağlık çalışanları binalara girerek sağlık hizmeti vermek noktasında geri durmuş, binalara güvenme noktasında tereddütler yaşamışlardır. Afetzedeler ve sağlık çalışanları imkânsızlıklar nedeniyle bireysel hijyenlerini sürdürme noktasında sorunlar yaşamışlar tuvaletlerin hijyenik olmadığı görülmüştür. Hemşireler ve diğer sağlık personelinde zorlanmalar nedeniyle gelişen bina fobisi, yorgunluk ve kaygıgan kaynaklanan "karar verme yetisinde" kayıplar gözlemleniştir. Deprem nedeniyle her an daha büyük bir deprem olabileceği ve mevcut binaların da yıkılabileceği düşüncesi ve kaygısı, sağlık çalışanlarının ailelerinde parçalanmalara neden oluşturmuş çocukların anne babalarının yanından ayrılıp, uzak akrabaların yanına gitmeleri gerektiği inancının oluştuğu gözlemlenmiştir. Bu bağlamda kentsel çevre açısından oluşan yıkıntıların kaldırılması çadırların ve prefabrik yaşam ortamlarının planlı bir şekilde kısa sürede kurulması önemlidir.

\subsection{Van Depreminden Çıkarılan Dersler}

Afetlerde yaşanan temel sorunlar göstermektedir ki etkin sağlık insan gücü planlaması, etkin sağlık hizmeti sunma ve sağlık çalışanlarına travma sonrası destek vermek afetzedelerin ve sağlık çalışanlarının sağlı̆̆ı, hizmetlerin sürdürülebilirliği açısından oldukça önemlidir (Fullerton 2004). Bu bağlamda Van depreminden çıkarılması gereken dersler gelecekte afet planlaması açısından oldukça önemli olup, aşağıdaki şekilde sıralanmıştır. 
Liderlik: Lider kim olacak? Afete yanıt planlarının dizayn edilmesine yardımda, afet yönetiminde, afet sonrası yönetim işlerinde liderlik pozisyonunda kimin olması gerektiği hangi kurumun ya da meslek gruplarının olması gerektiği, hangi sivil toplum kuruluşlarının görev alması gerektiği, tartışılmalıdır. Zira Van depreminde de görülmüştür ki deprem sonrasında lojistik açıdan oluşan sorunların giderilmesi vakit almış ve herkesin iyi niyetli hareket etmesine rağmen kargaşa oluşmuş ve etkin bir afet yönetiminden bahsedilememiştir. Afet yönetiminde etkili bir liderlik, etkinlik, verimlilik, güç, esneklik, yaratıcılık ve işbirliği yaklaşımlarının kullanımını gerektirir (Alleyne 2010). Bu bağlamda afetlerde görev alan kamu kurumları, sivil toplum kuruluşları ve gönüllüler arasında bir işbirliği yapılarak hangi alanların kamunun liderliğine bırakılması gerektiğine hangi alanların sivil toplum kuruluşlarına ve hangi durumların gönüllülere bırakılması gerektiğine karar verilmelidir. Örneğin Van depreminde görüldüğü üzere kamu kurumları vakit kaybetmeden bir takım sorunlara rağmen üzerine düşeni en etkin şekilde gerçekleştirmiş ancak sivil toplum kuruluşlarının görev tanımlarının net olmaması nedeniyle hangi alanlarda görev alacakları konusunda bir takım sıkıntılar oluşmuştur. Bu noktada afetlerde etkin rol alacak paydaşların afetlerde hangi alanlarda görev alması gerektiği ve hangi konularda liderlik yapacaklarının net olarak belirlenmesi görev karmaşalarının önüne geçilmesi açısından Van depreminden çıkarılmış en temel derslerden biridir.

Rol ve fonksiyonlar: Afete öncesi, anı ve sonrasında görev alacak personellerin rol ve fonksiyonları neler olması gerektiği bu rol ve fonksiyonları afet psikolojisi içerisinde ne kadar sürdürebilecekleri bilinmeli, planlanmalı ve etkin bir şekilde yönetilmelidir. Afet sürecinde görev alacak personellerin rollerinin neler olacağının tanımlanması ve bu rol ve fonksiyonlara göre eğitilmeleri gerekmektedir.

Politika gelişimi: Türkiye Ulusal Afet Yönetim Politikası oluşturulurken uluslararası örgütlerin STK'ların deneyimlerinden yararlanılmalıdır. Afet yönetimi açısından uluslararası deneyimler ve ülkelerin yasal düzenlemeleri afet yönetim politikaları, afetlerde görev alanlara yönelik eğitim programları ve içerikleri Türkiye Ulusal Afet Yönetim Politikasının oluşumunda göz önünde bulundurulmalıdır.

Kurum ve kuruluşların etkinliği: Devlet kurum ve kuruluşlarının ulusal afete yanıt planlarını etkin bir şekilde uygulayabilecek personel, teknik altyapı ve donanımları bulunmalı ve profesyonel bir şekilde afetlere müdahale edebilmelidir. Örneğin kan ihtiyacı konusunda ilgili kurum kuruluşun etkinliği afetzedelerin hayatta kalmalarına etki edecek önemli faktörlerden biridir. Bu noktada Kamu kurumları afet sürecinde etkin kamuoyu açıklamaları ile daha etkin olmasının sağlanması gerekmektedir.

Halk sağlı̆̆ının korunması: Van depremi sonrasında halk sağlığının korunması ve birinci basamak sağlık hizmetleri sunulması sürdürülebilirliğinin sağlanmasında aksamalar olduğu görülmüştür. Özellikle üst - alt solunum yolu hastalıkları, viral ishaller önemli sorunlar olarak gözlemlenmiştir. Afetzedelerin gıda, barınma, içme suyu, ısınma, kıyafet, yıkanma, çöp - atık uzaklaştırma vb gereksinimlerinin sağlıklı olarak sağlanmasında sorunlar olduğu tespit edilmiştir. Uygun barınma ve sanitasyon şartlarının sağlanmasında sorunlar yaşandığı ve alt yapı hizmetlerinde sorunlar olduğu görülmüştür. Halk sağlığının korunması açısından bu noktalardan dersler çıkarılması gerekmektedir.

Sürveyans: Afet sonrası sürece yönelik sağlığın geliştirilmesi ile ilgili olarak sürveyans çalışmalarına ihtiyaç bulunmakta olup bu konuda eğitimsel programlara ihtiyaç olduğu görülmektedir.

Bakımın kalitesi: Afetlerde kaliteli bakım nedir ne olmalıdır konusunda afet sonrası süreçte standart bakımın çok altında uygulamalar oluşabilmektedir. Afet durumlarında kaliteli bakım sağlamak için bir yol bulunmalı afetlerde olması gereken bakım kalitesi standartları belirlenmelidir.

Kanıta dayalı uygulamalar: Afetlerde uygulanan sağlık bakımları kanıta dayalı uygulamaları içermelidir. Afet sonrasında yaralıların bakımlarında yerel ve kültürel uygulamaların uygulanması ile afetzedelerin sağlıkları olumsuz etkilenebilmektedir. Bu bağlamda kanıta dayalı olmayan kültürel bir takım uygulamalardan uzak durulması konusunda dikkat edilmelidir.

Ĕ̆itim: Dünyadaki ve Türkiye'de doğal ve doğal olmayan afetlerle karşılaşmak açısından tüm sağlık disiplinleri için afetlere hazır olmak çok önemli bir konudur. Bu nedenle tüm sağlık profesyonellerinin afet yönetimi konusunda bilgili olmaları hayati bir önem taşımaktadır (Fountain vd. 2014; Alim vd. 2014). Bu durum afetler ve afet yönetimi konusunda eğitimli sağlık personeline olan gereksinimi ve bu personelin vereceği hizmetin gerekliliğine olan inancı ve ihtiyacı tüm dünyada artırmıştır. Afet hemşiresinin kendisinden beklenen nitelikler doğrultusunda hizmet verebilmesi için rol ve sorumlulukları, eğitimi, hizmet kapsamı ve afet hemşireliği alanındaki araştırmalar gibi birçok konunun ele alınması gerekmektedir. Bu gereksinim ülkemizde de afet yönetimi alanında çalışanların görünür kılınmasının, personelin çağdaş rol ve fonksiyonlarına uygun olarak görev tanımlarının yapılması, çalışma alanı bulması ve eğitim alt yapısının oluşturulması için önemli bir gereklilik olarak değerlendirilebilir (Kalanlar 2015). Bu bağlamda; afetlerde görev alacak personeller için eğitimsel ihtiyaçlar nelerdir, tespit edilmeli eğitim programları hazırlanmalıdır. Tüm alanlarda çalışan bütün personeller, ilk yardım gibi temel yetkinlikleri öğrenmelidirler.

Eleştirel Düşünme Becerisi: Eleştirel düşünme afet yönetiminde oldukça önemlidir. Afet koşullarının doğası, sakin kalmayı ve kritik düşünmeyi gerektirir. Bu süreçte elbette ki hatalar oluşacaktır. Ancak bu hatalardan ders alınmalıdır. Süreç yönetiminde eleştirilerin yıpratıcı ve demoralize edici olmaması önemlidir.

İşbirliği: Ulusal, uluslararası, disiplinler içi ve disiplinler arası işbirliği afet durumlarında kritik öneme sahiptir. Bu bağlamda her türlü yardım teklifi değerlendirilmeli ancak reklam mahiyetindeki yardımlara izin verilmemeli afetzedelerin durumlarının istismar edilmesine imkân verilmemelidir. 


\section{Sonuç ve Öneriler}

Afetlerde yaşanan deneyimlerin bilgi olarak aktarılması, kentlerin gelecekte yaşanacak depremlere hazırlıklı olmak açısından oldukça önemlidir. Kentsel çevre ve sağlık açısından depremlerde etkin planlama yapılması, ölüm ve yaralanmalar için risk faktörlerinin epidemiyolojik analizi, depremlerde acil ihtiyaç değerlendirmesi için gerekli bilgi, kurtarma faaliyetleri, kayıpların yönetimi, tıbbi malzemeler, hastalık kontrol ve sanitasyon ve dış yardım konularının deprem öncesi, sırası ve sonrasında olmak üzere afetin tüm evrelerinin önceden planlanması gerektiği değerlendirilmektedir. Ayrıca kentsel çevre ve sağlık bağlamında afete hazırlıklı olma noktasında kentlerimizde veya belirlenecek ortak noktalarda kışlık çadır, konteyner depoları oluşturulması gerektiği, depolarda afetzedeler için ve sağlık personelleri için gerekli uyku tulumu, stok imkânı bulunan malzemelerin bulundurulması ve yedeklenmesi gerektiği çıkarılan bulgulardandır.

Van depremi sağlık çalışanları açısından değerlendirildiğinde önemli bir veri kaynağıdır. Van depremi sırasında ve sonrasında sağlık çalışanları birçok problem ile karşı karşıya kalmıştır. Bu problemler sağlık çalışanının kişisel özelliklerinden kaynaklanabildiği gibi afet yönetiminde ki yetersizliklerden de kaynaklanmıştır. Bu bağlamda dünya örnekleri ve Van depremi özelinde değerlendirmelerde bulunulduğunda sağlık çalışanlarının afetler konusunda eğitilmelerinin gerekliliği ön plana çıkmaktadır. Ancak bu eğitim Van depreminde ortaya çıkan tecrübeler 1şı̆̆ında salt teorik eğitimden ziyade pratiği de içermeli ve afetlerde görev alan tüm paydaşların bu eğitimlerde yer alması sağlanmalıdır. Bir diğer olgu ise afet çalışanlarının psikolojik yıpranmalarıdır (Ozan ve Sir 2004; Polatin vd. 2005; Stellman vd. 2008). Bu noktada Van depreminden çıkarılan ders sağlık profesyonellerine afet bölgesinde çok iyi şartlarda yer temin edilmesi ve kalma sürelerinin kısa tutulmasıdır. Ayrıca afetten sonra afette görev alan personele psikolojik destek sağlanmasının da yerinde olacağı gözlemlenmiştir. Van depreminden çıkarılan üçüncü ve en önemli ders ise sağlık çalışanlarının afet yönetiminin her aşamasında yer almasının gerekliliğidir. Son olarak Van depremi afetzedelerin yaşadığı sorunlar açısından değerlendirildiğinde demoralize olmuş, yakınlarını ve mal varlığını kaybetmiş psikolojik olarak tükenmişlik noktasına gelmiş afetzedelerin yeterince desteklenemediği, sağlık ve hijyen koşullarının çok iyi nitelikte sağlanamadığı, bu konularda ki çalışmaların olması gerekenden daha ileri safhalara ötelendiği gözlenmiştir. Bu noktada en fazla sıkıntı dezavantajlı gruplar olarak nitelenen kadınlarda, yaşlılarda ve çocuklarda gözlenmiştir. Sağlık çalışanlarının bu hususta harekete geçmeleri ve gerekli tedbirleri almaları gereğinden fazla zaman almıştır. Çocukların ihtiyaçlarının karşılanması, kadınların ihtiyaçlarının karşılanması konusunda afet yöneticilerinin tedbir almakta zorlandıkları görülmüştür. Van depreminde sağlığın geliştirilmesi açısından çıkarılması gereken en önemli derslerden bir tanesi ise afete hazırlık, afet sırası ve sonrası için bir yapılacaklar listesinin olmaması nedeniyle zamanında yapılması gerekenlerin yapılamaması, iş akışlarının önem sırasının ortaya konulamamasıdır. Bu noktada afet yönetimi etkin bir yönetimden ziyade yöneticinin bilgi birikimine, mesleki bilgisine, o an içinde bulunduğu psikolojisine ve çevresinde ki faktörlere göre sürekli değişebilmektedir. Etkin bir afet yönetiminde ise iyi bir eğitim ile sağlık profesyonelleri afetlerde daha etkin bir rol alarak gerek afetzedelerin deprem anında kurtarılmasında gerekse afetten sonraki iyileşme süreçlerinde sağlıklarının geliştirilmesine katkı sağlayacaktır. Bu noktada Van depremi konuya bilimsel açıdan bakıldığında önemli bir veri kaynağı olarak değerlendirilmelidir. Van depreminden çıkarılan derslerin ilgili paydaşlarca önemsenmesi, tecrübelerin paylaşılması ve bu konuda daha fazla bilimsel çalışma yapılması ile afetlere hazırlık ve afet yönetimi konularında daha profesyonel bir yaklaşım sergilenebilir.

Bireylere ve topluma afet öncesi, afet sırası ve afet sonrasında etkin bakım verebilmek için, sağlık personelinin afet öncesi, sırası ve sonrasına ilişkin girişimlerini bir bütün içinde uygulaması gerekmektedir. Sağlık personelinin en önemli hedefleri bireyler açısından afet sürecinde olumlu sağlık davranışlarını geliştirmek, halk sağlığı açısından ise afetlerde daha az can kaybı, yaralanma ve sağlık sistemine daha az etki ile olumlu katkılar sağlamaktır. Bu konularda beklenen gelişmenin sağlanabilmesi için eğitim, araştırma ve geliştirme faaliyetlerine önem verilmesi, bu yönde yapılan çalışmaları destekleyecek yasal düzenlemelerin olması çalışmanın en temel önerisidir.

\section{Kaynaklar}

Alim S., Kawabata M., Nakazawa M., (2014), Evaluation of disaster preparedness training and disaster drill for nursing students, Nurse Education Today, 35(1), 25-31.

Alleyne G., (Ed.), (2010), Natural disasters protecting the public's health, World Health Organization, Washington, USA, 92ss.

Fountain R., Chilton J., Deal B., Connor D., Hensarling J., Klotz L., Alfred D., (2014), Preparing for disasters: education and management strategies explored, Nurse Education in Practice, doi: 10.1016/j.nepr.2014.08.001.

Fullerton CS., Ursano RJ., Wang L., (2004), Acute stress disorder, posttraumatic stress disorder, and depression in disaster and rescue workers, American Journal of Psychiatry, 1(61), 1370-1376.

Hinton WP., Garmon SC., Elberson KL., (2005), Research issues in preparedness for mass casualty events, disaster, war, and terrorism, The Nursing Clinics of North America, 40(3), 551-564.

Kalanlar B., (2013), Afet hemşireliği ve yönetiminin hemşire öğrencilere öğretimi: Jenning in hemşirelikte afet yönetim modelinin kullanılması, Doktora Tezi, Hacettepe Üniversitesi, Ankara, Türkiye.

Kalanlar B., (2014), Afetlerde hemşirelerin yaşadıkları psiko-sosyal sorunlar ve çözüme yönelik öneriler, Sağllk ve Toplum Dergisi, 24(1), 15-23.

Kalanlar B., Kubilay G., (2015), Afet hemşireliği ĕgitimi ve afet öncesinde afet hemşiresinin görevleri, Dokuz Eylül Üniversitesi Hemşirelik Yüksekokulu Dergisi, 8(2), 77-85. 
Kalanlar B., (2015), Afetlerde toplum sağglı̆ının korunmasında önemli bir kavram: afet hemşireliği. Florance Nightingale Hemşirelik Dergisi, 23(1), 57-65.

Kalanlar B., (2012), Afetlerde hemşirelik uygulamaları: Japonya ve Van depremlerinin afet hemşireliği açısından değerlendirilmesi. Acil ve Afet Dergisi, 1(2), 21-28.

Kennedy B., Carson D.S., Garr D., (2009), South Carolina area health education consortium disaster preparedness and response training network: An emerging partner in preparedness training, Journal of Public Health Management Practice, 15(2), 13-19.

Minami H., Young S., (Ed.), (2009), ICN framework of disaster nursing competencies, World Health Organization and International Council of Nurses, Geneva, Switzerland, 66ss.

Ozen S., Sir A., (2004), Frequency of PTSD in a group of search and rescue workers two months after 2003 Bingol (Turkey) earthquake, Journal of Nervous and Mental Disease, 192, 573-575.

Polatin PB., Young M., Mayer M., Gatchel R., (2005), Bioterrorism, stress and pain: the importance of an anticipatory community preparedness intervention. Journal of Psychosmatic Research, 58(4), 1-6.

Pınar A., Kalafat D., Zülfikar C., (2012), The Van earthquake seismicity tectonics, http://koeri.boun.edu.tr, [Erişim 6 Nisan 2016].

Priest C., (2009), Catastrophic conditions, tough decisions: The roles and responsibilities of nurse leaders in disaster settings, Nurse Leader, 7(3), 48-50.

Stellman JM., Smith RP., Katz CL., (2008), Enduring mental health morbidity and social function impairment in world trade center rescue, recovery, and cleanup workers: the psychological dimension of an environmental health disaster, Environmental Health Perspectives, 1(16), 1248-1253.

Slepski LA., (2007), Emergency preparedness and professional competency among health care providers during hurricanes Katrina and Rita: pilot study results, Disaster Management and Response, 5, 99-110.

URL-1,(2011), Başbakanlık Afet ve Acil Durum Yönetimi Başkanlığı (AFAD), Van depremleri faaliyet raporu, http://afad.gov.tr/faaliyetler/van-faal.html [Erişim 1 Nisan 2016].

URL-2, (2016), Türkiye Deprem Haritası. Van İlinde Son 5 Yılda Meydana Gelen En Büyük Depremler, http://depremler.org/ [Erişim 10 Nisan 2016].

Veenema T.G., (2003), Essentials of disaster planning, Disaster Nursing and Emergency Preparedness for Chemical, Biological and Radiological Terrorism and Other Hazards'ın İçinde, (Veenema T.G., Ed.), Springer Publishing Company, New York, ss.3-29. 